\title{
THE QUALIFICATION, CLASSIFICATION, OR CHARACTERIZATION PROBLEM IN THE CONFLICT OF LAWS
}

\author{
BY ERNEST G. LORENZEN†
}

I.

THE problem in the Conflict of Laws which today is known on the continent as the problem of "qualification" and in recent Anglo-American literature as that of "classification" or "characterization" was brought to the attention of students of the Conflict of Laws fifty years ago. In the very year of the founding of the Yale Law Journal, Franz Kahn published an article in Jhering's Jalirbücher ${ }^{1}$ in which he pointed out that even if the rules of the Conflict of Laws in the different countries were the same, identity of results in individual cases would not follow because of latent conflicts inherent in the different systems of law.

Bartin dealt with the same problem in 1897, under the title $D e$ l'impossibilité d'arriver à la suppression définitive des conflits de lois, apparently unaware of the fact that Kahn had written on the subject before him. Bartin spoke of the problem as one of "qualification," and since that time the problem has been known on the continent by that name.

There is no agreement among the writers concerning the type of questions properly belonging to a discussion of the qualification problem. Some use the term in a very broad sense and others in a narrower sense. I shall deal with the following classes of cases:

(1) The first class is one in which the fact situation is characterized under the law of the forum in a way different from that in which it is characterized under the lex causae - the law of the state or country with which it is connected. It may be regarded by one law as presenting a question of contracts and by the other law as a question of torts or property, by one law as a question of matrimonial property and by the other

†Edward J. Phelps Professor of Law, Yale Law School.

1. Kahn, Gesetzeskollisionen: Ein Beitrag zur Lelire des internationalcn Privalrechts (1891) 30 JHERING'S JAHRBÜCHER FÜR DIE DoGaMATIK DES HEUTIGE: Rö:UISCaE:

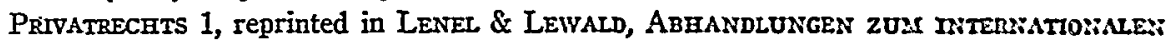
Privatrecht (1928) 1.

2. 24 Clunet 225. Beckett was the first to suggest that "classification" was linguistically a better term in English than "qualification." The Questions of Classification ("Qualification") in Private International Law (1934) 15 Bart. Y. B. IsT. L. 46, n. 3. Faiconbridge regards the term "characterization" as the most suitable English word. Characterization In The Conflict of Laws (1937) 53 L. Q. REv. 235, 239, n. 17. Nussbaum admits that "characterization" is linguistically more correct, but thinks that the internationally accepted technical term "qualification" should be given preference in a discussion of international import. Book Review (1940) 40 CoL. L. Rev. 1461, n. 2. 
law as a question of succession, by one law as a question of succession and by the other law as a question of administration. Because of these divergencies in classification, different rules of the Conflict of Laws may become applicable. The problem is whether the qualification or characterization is to be made on the basis of the law of the forum or on that of the foreign law.

The same problem may also arise in situations in which the law of the forum and that of the foreign country differ as to whether certain property is movable or immovable, or in which they differ on questions of capacity and form. Are these questions to be resolved on the basis of the law of the forum or on the basis of the foreign law?

(2) The second class of cases involves the qualification of the connecting factor. A choice-of-law rule of the forum may determine legal relations by reference to the law of domicile, the law of the place of contracting, the law of the place of performance, or the law of the place where the tort is committed. The terms "domicile," "place of contracting," "place of performance," or "place of the wrong" are here connecting factors. The law of the forum and the foreign law involved may have the same connecting factors in their systems of the Conflict of Laws but different meanings may be attached to them. Here again the question is whether the meaning of these connecting factors should be determined in the light of the law of the forum or of the foreign law.

(3) A third class of cases arises after the applicable foreign law has been selected by the law of the forum. Here again the law of the forum and the foreign law may entertain different views as to whether a provision of the foreign law is to be regarded as substantive or procedural, a decision upon which the applicability of different laws may depend. How is this question to be determined?

It should be noted that in each of the above classes of cases the choice of law depends upon the qualification problem. If the problem is answered on the basis of the law of the forum, one law becomes applicable; if it is answered on the basis of the lex causae, another law determines the solution of the case. By limiting this discussion to these three classes, it will be possible to deal with the subject of qualification without running over the entire field of the Conflict of Laws, and to give some sort of unity and cohesion to the treatment.

The assertion has been made that real qualification questions have been presented in only a few cases and that the problem is therefore devoid of practical interest. ${ }^{3}$ The enthusiastic discussion which the qualification problem has evoked has been ascribed as due largely to an unrealistic approach to the Conflict of Laws, principally exhibited by the adherents of the "logistic school." This school, it is said, attempts to perpetuate"

3. Nussbaum, Book Review (1940) 40 CoL. L. Rev. 1461, 1468-1469. 
an international point of view in the Conflict of Laws on grounds of pure logic after it has become apparent that the law of nations cannot furnish an adequate basis. ${ }^{4}$ It is true that there have been, relatively speaking, only a few decisions in which a court has been clearly confronted with the necessity of choosing between the qualification of the forum and a qualification which would be different under the lex causae." As between states and countries belonging to the common law group, the categories in which fact-situations are grouped are generally the same, so that there is usually little occasion for the problem of qualification, although even here cases of this sort have presented themselves. The problem may readily arise, however, where the common law comes into contact with the civil law. It has practical, as well as scientific, importance and for that reason deserves consideration.

Both Kahn and Bartin concluded that no uniform solution could be found which would answer the above problems and that each forum would have to deal with them on the basis of its own internal law. Despagnet attempted to bring about uniformity by suggesting that the questions be referred to the lex causae, the law governing the legal transaction in question. ${ }^{6}$ Another writer, Gemma, realizing, no doubt, the impossibility of qualifying legal transactions by the le.x cansue (i.e., on the basis of some law which remains yet to be ascertained), proposed to reach uniformity among the different countries by qualifying legal transactions with reference to the requirements of international life. ${ }^{\top}$

My own reactions to the problem in the light of the existing AngloAmerican decisions were set forth in an article published in 1920, in which I agreed in the main with the conclusions of Kahn and Bartin, that there is generally no escape from applying the internal law of the forum to the qualification of legal transactions. ${ }^{8}$ In common with some foreign writers, however, I favored these exceptions: (1) that the qualification of rights affecting tangible property should be made on the

4. Id. at 1469,1470 .

5. Nussbaum cites the following: Harral v. Wallis, 37 N. J. Eq. 458 (1883), aff'd sub nom. Harral v. Harral, 39 N. J. Eq. 279 (18S4) (domicile); Wood \& Selick v. Compagnie Générale Transatlantique, 43 F. (2d) 941 (C. C. A. 2d, 1930) (statute of limitations); University of Chicago v. Dater, 277 Mich. 65S, 270 N. W. 175 (1936) (contract, lex loci contractus); St. Louis-S. F. R. R. v. Fox, 171 Ark. 103, 283 S. W. 31 (1926) (settlement of injury claim rescinded, mode of tender) ; if. Ronerssos, CrnasACTERIZATION IN THE CONFLICT of LAWS (1940) 157-222, 235-279 (hereinafter cited as Robertson); New England Mfutual Life Ins. Co. v. Spence, 104 F. (2d) 665 (C. C. A. 2d, 1939).

6. Des conflits de lois relatifs à la qualification des rapports juridiques, 25 Clunet 253, 261, 262; also PRÉCIS dE DROTT INTERNATIONAL pRtvé (1909) 353 et scq.

7. Propedeutica AL DIRTTTO INTERNAzIONALE PRIVATo (1899) 91, 111-112.

8. The Theory of Qualifications and the Conflict of Law' (1920) 20 COL L. Rev. 247. 
basis of the lex rei sitae, ${ }^{9}$ and (2) that if the forum is interested in a case only insofar as it is the place of trial, the courts of the forum should follow a qualification agreed upon by the foreign states or countries concerned. .10 $^{10}$

Since 1920, the continental literature on the subject has assumed vast proportions. ${ }^{11}$ The great majority of writers have been forced to agree with Kahn and Bartin; and Despagnet's view that the lex causae should determine the question has found but a very few followers. ${ }^{12}$ Gemma's attempt to supplant the use of the internal law both of the lex fori and of the lex causae with a consideration of the international requirements has led to some important developments in recent years. The most outstanding effort in this direction has been made by Rabel. ${ }^{13}$ According to this eminent writer, it is a mistake to assume that the sole background of a choice-of-law rule is the material law of the forum. Each country's rules of private international law are designed, in his view, to bring about international harmony between the law of the forum and that of all other countries, which can be attained only on the basis of more abstract notions than the concrete institutions of any particular country. Notwithstanding great diversities in the legal institutions of civilized countries, Rabel contends, they generally resemble each other sufficiently to permit the creation of more abstract notions which are valid for all national legislations. By way of illustration he takes the subject of "Guardianship" referred to in Article 23 of the Introductory Law of the German Civil Code, which he would understand as an abstract notion of guardianship derived from a comparative study of the institution in the entire civilized world instead of as referring merely to guardianship as understood in German internal law. Rabel admits that the method of comparative law will not resolve the problem of qualification in those cases where the differences between the legislations are so great that it is impossible to set up a compromise between the opposing points of view.

9. See, in general, Falconbridge, Contract and Conveyance in the Conflict of Lan's (1933) 81 U. oF PA. L. REv. 661, 663-666, 682-683; Characteriation in the Conflict of Lazus (1937) 53 L. Q. REv. 235, 543; Conflict of Lazes: Examples of Characterization (1937) 15 CAN. B. Rev. 215, 234; RoBertson 190 et seq.

10. Accord, RoBertson 177. If all the operative facts occurred in a single foreign country the law of that country would, of course, control without regard to whether the question was characterized in one way or another. The only exception to the rule would be for matters which the law of the forum would deem to be procedural.

11. For the bibliography, see RoBERTson xxv-xxix; for a representation in English of the Italian viewpoint, see Meriggi, Conflicts of Law-A Theoretical Approach (1934) 14 B. U. L. REv. 319.

12. E.g., Wolff, Internationales Privatrecht (1933) 37; Pacchion, Dikitto Internazionale Privato (2d ed. 1935) 173.

13. Das Problem der Qualifikation (1931) 5 ZeITSChrift Für AUSLÄNdisches UND internationales Privatrecht 241. Republished in revised form in Italian: $l l$ Problema della Qualificazione (1932) 2 Riv. Int. pi Dir. Privato e Processuale 97, and in French: Le Problème de la Qualification (1933) 28 Rev. DE DR. INT. Prive 1. 
In 1930 Bartin $^{14}$ added the following limitation to his original thesis that the lex fori governed the qualification of legal transactions: "After the law of the forum, on the basis of its own qualification, has chusen a foreign law as governing a particular legal institution, all subsidiary qualifications arising thereafter and necessary for the decision of the case are determined by the foreign law."

In 1932 Neuner ${ }^{15}$ published the first monograpli on the subject, in which he rejected all the foregoing conclusions, the problem of qualification having, in his opinion, no right to existence. According to this author, the fundamental error consists in the assumption that there exists in each country a body of choice-of-law rules which are applicable tu all situations that may be presented to a court, whereas there are actually only about twenty or thirty such rules, which are entirely inadequate for that purpose. The primary need is, therefore, the working out of additional rules, together with the further elaboration of the existing rules and their application in a manner calculated to bring about reasonable and just results. ${ }^{16}$

Recently, English and American writers also have begun to take interest in the problem of qualification. Beginning with 1934, a series of articles which dealt with the subject appeared. The earliest was by Beckett, ${ }^{17}$ who conceived the proper principle to be that the classification should be made on the basis of analytical jurisprudence and comparative law. Like Rabel, he felt that if the rules of Conflicts are to perform the function for which they are designed, they must be applied in a manner suitable for appreciating the character of the rules and institutions of all legal systems. The conception of these rules must, therefore, be of a very general character, which can be derived only from analytical jurisprudence and comparative law.

14. 1 Princtpes de Dr. INT. Pruvé (1930) 235; La Doctrine des Qualifications at ses rapports avec le caractìre national des règles din Conflil des Lois (1930) Acuob́zue DE DR. INT., REC des Cours I, 565-620. See also Mraury, Règles Gínćrales des Conflits de Lois (1936) ACADÉAIIE DE DR. InT., REc. DES Cours III, 329, 493 ef seq.

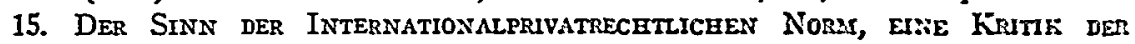
QuALIFIKATIONSTHEORIE (1932).

16. Neuner says that the Conflict of Laws rules are not as general as they are brlieved to be and as they must be deemed to be if they are to govern all cases. In his view they are only general propositions, the extent and application of which remain to be worked out. The case of Ogden v. Ogden, infra p. 755, may serve as an illustration. According to Neuner the English courts never really adopted the broad rule that capacity to marry is governed by the law of domicile but adopted it only with respect to prohibited degrees of relationship. As the law of the place of celebration in all other respects governs marriage in English law, it would therefore also apply to the question of parental consent. Such an interpretation of the English law would, of course, climinate the qualification problem.

17. The Question of Classification ("Qualification") in Private Intcrnational Law (1934) 15 BRIT. Y. B. INT. L. 46. 
Beckett's conclusions were accepted by Cheshire in the first edition of his textbook in $1935 .{ }^{18}$ In the second edition in $1938,{ }^{10}$ Cheshire draws a distinction between primary classification, arising before the law applicable to the case is selected, and secondary classification, which arises after the selection of such law. ${ }^{20} \mathrm{He}$ would determine the former with reference to the lex fori and the latter with reference to the lex causac. This division corresponds to Bartin's later views.

In 1940 Robertson published a comprehensive monograph on Characterization in the Conflict of Lawes. ${ }^{21}$ As his work contains a detailed examination of the views of all Anglo-American writers, and of the most important continental writers, as well as a discussion of most English and American cases presenting fact situations involving the problem of characterization, our further development of the subject will center its attention upon the conclusions reached by this author.

II.

Falconbridge was the first writer to suggest that the problem of qualification should be considered in connection with each of the different stages presented in the solution of a Conflicts problem. ${ }^{22}$ Before a judge can select the choice-of-law rule applicable to a situation presented to him, he must know whether the question relates to contracts, torts, property, succession, or some other field. He will usually be quite sure of the category to which the question belongs. Many differences do exist, however, between the different systems of law in the classification of legal transactions, and the question is what a judge is to do when confronted with a situation treated variantly in different systems. Most writers seem to feel that in the present stage of our law there is no practical alternative to the application of the law of the forum. ${ }^{23}$ It is conceded that this is an undesirable state of affairs because different solutions will be reached in different countries having identical Conflicts rules. Vigorous efforts

18. Cheshire, Private International Law (1st ed. 1935) 14.

19. Id. (2d ed. 1938) at 24-25.

20. Cheshire, Private International Law (2d ed. 1938) 30, 37. For a discussion of secondary classification, see p. 753 et seq. infra.

21. For other articles on the subject by English and American writers, see Falconbridge, Characterization in the Conflict of Lazes (1937) 53 L. Q. REv. 235, 537; Conflict of Lazes: Examples of Characterization (1937) 15 CAN. B. REv. 215; Renvoi, Characterization and Acquired Rights (1939) 17 CAN. B. Rev. 369; Unger, The Place of Classification in Private International Law (1937) 19 BELL YARD 3; Cheatham, Internal Law Distinctions in the Conflict of Lawe (1936) 21 CoRN. L. Q. 570.

22. Characterization in the Conflict of Lazes (1937) 53 L. Q. REv. 235, 236.

23. Falconbridge is in accord, but he urges that in order to bring about reasonable economic or social results the process of selecting the proper law be rendered as flexible as possible. He suggests, therefore, that the characterization should be made in the light of all potentially applicable rules of law. Renvoi, Characterization and Acquired Rights (1939) 17 CAN. B. Rev. 369, 374-375. 
have therefore been made to avoid this conclusion, but, except in one or two directions, ${ }^{24}$ no practical escapes have been found.

Robertson is in general agreement with the above views but contends that further clarification is necessary concerning the process of qualification by the lex fori. He makes particular objection to the statement that the qualification must be on the basis of the "internal" law of the forum. ${ }^{25}$ Unger called attention to this point in connection with two English cases. ${ }^{26}$ One involved a foreign contract unsupported by consideration. The contract, being governed by the foreign law and valid there, was enforced in England. ${ }^{27}$ If the court had applied the strictly internal law, which required that a contract be supported by cunsideration, the fact-situation presented could not have been characterized as a contract. Unger holds, therefore, that it is sufficient if the case falls within the "analytical framework" of the legal system of the forum. The second case recognized the validity of a Russian marriage in England. ${ }^{23}$ As a Russian marriage is terminable at will, it does not correspond to the English notion of marriage. Unger would say that the Russian marriage was rightfully recognized in England because it fell within the English analytical framework concerning marriage. Robertson regards Unger's formulation of the rule as still too narrow because it does not include cases involving foreign institutions entirely unknown to the internal English law. Such a situation was presented to the House of Lords in the case of DeNicols v. Curlier. ${ }^{29}$ A French couple came to reside in England. At the husband's death, the widow claimed one-half of all the property acquired by the husband during the marriage, including the property acquired in England, basing her claim on the French matrimonial property régime. No such property régime was known to the internal English law. The House of Lords felt that the French law should control and, in so holding, recognized a foreign institution which did not exist in England and so could not fall within the framework of the English internal law. Robertson therefore concludes that, insofar as the characterization of foreign legal situations is determined by the le.x fori, the term does not mean the strictly internal law of the forum, but a wider concept which needs to be worked out for purposes of the Conflict of Laws. ${ }^{30}$ This conclusion clearly seems to be correct.

In my Article dealing with the statute of frauds, ${ }^{31}$ published in 1923 , I was already aware that qualification in accordance with the internal law

24. See pp. 744-745 supra.

25. ROBERTSON 29 et seq.

26. Unger, suṕra note 21 , at 7.

27. Re Bonacina [1912] 2 Ch. 394 (C.A.).

28. Nachimson v. Nachimson [1930] P. 217.

29. [1900] A. C. 21.

30. ROBERTSON 89.

31. The Statute of Frauds and the Conflict of Laits (1923) 32 Yale L. J. 311. 
of the forum would not do. In most instances the categories of internal law will also suffice for purposes of the Conflict of Laws but there are situations where they may not. In the Article referred to, I stated that the statute of frauds might well be classified as procedural for purposes of internal law and yet be substantive from the point of view of the Conflict of Laws. ${ }^{32}$ The clearest example of such a distinction in AngloAmerican law relates to "penal" laws. There have been many American decisions holding that a statute which gives a plaintiff damages in excess of the amount of his loss, or without reference to such amount or the cause of the loss, is a penal statute. The United States Supreme Court ${ }^{\text {g3 }}$ and the English Privy Council ${ }^{34}$ have held, however, in Huntington $v$. Attrill that, for purposes of the Conflict of Laws, an international test should be adopted, restricting the definition of a penal law to a law punishing a person for the infraction of a public law. Here we have two distinct tests of what constitutes a penal law, one for internal law purposes and the other for questions of the Conflict of Laws. Similarly, as regards the qualification of legal transactions, the classification or characterization may have to be upon a broader or narrower basis than the internal law of the forum if it is to be suitable for the needs of the Conflict of Laws. In certain cases it may suffice, as suggested by Unger, that the transaction fall within the analytical framework of the internal law of the forum. In other cases it may not, so that wider categories may have to be discovered. ${ }^{35}$ To this end a knowledge of Comparative Law may be useful.

\section{III.}

Let us consider next the characterization of the connecting factor. After having reached the conclusion that the situation presented to the court is one of succession, or one of contracts or torts, the judge will be directed by the choice-of-law rules of the forum to apply the law of the domicile, the lex loci contractus, the lex loci solutionis, or the lex loci delicti, respectively. He may find, however, in a given case that different meanings are attached to such connecting factors. For example, the English courts recognize the reverter doctrine in connection with domicile. Our courts do not. In the English law a married woman cannot acquire

32. Id. at 330 .

33. Huntington v. Attrill, 146 U. S. 657 (1892).

34. Huntington v. Attrill [1893] A. C. 150 (P.C.).

35. In the cases used by way of illustration above, the characterization of the situation as "contract," "marriage," or "penal" may not have determined the choice of law within the strict meaning of the qualification problem as defined in this article. The question was in fact only whether a wide or a narrow meaning should be given to the terms in connection with the enforcement of the foreign "contract," or "penal" liability, or the recognition of the foreign "marriage." The same reasoning is valid, however, where a choice of law is dependent upon the qualification problem as herein defined. 
a separate domicile. Under our law she may. Under our law a contract by correspondence is deemed concluded when the letter of acceptance is posted. On the continent and in Latin-America, the formation of the contract is not infrequently postponed to the time when the answer reaches the offeror. Differences exist also with respect to the place of performance of a contract or the place where a tort is committed. On the continent the qualification of nationality as a connecting factor is of great importance because in many countries the lex patriae has been substituted for the lex domicilii in the determination of the personal law. As the laws governing the acquisition and loss of nationality vary considerably in the different countries, by what law is the judge to determine the nationality of the parties before him? I dealt with this problem in an earlier Article, ${ }^{36}$ and, as it has little practical importance in the AngloAmerican system of the Conflict of Laws, it need not be reconsidered here.

Apart from the qualification of "nationality," it may be said that there appears to be general concurrence, at least among Anglo-American courts and writers, ${ }^{37}$ that the law of the forum must determine the meaning of the connecting factors. Where a person lives in a single foreign country, it is, of course, quite simple to determine his domicile with reference to such foreign law. Difficulties would arise, however, if he were to live in several foreign countries unless there were agreement between those countries regarding his domicile. So far as the question has been presented to Anglo-American courts, they have determined domicile in accordance with the lex fori. ${ }^{38}$ Whether they would accept the common characterization of two foreign states to which the factual situation was exclusively related, the law of the forum being interested solely as the place of trial, is not certain. ${ }^{39}$ The foreign characterization might well be adopted in this situation in the interest of uniformity, as there is no inescapable necessity for applying the law of the forum. Similarly, with respect to the remaining factors. Thus in a contract case, if the law in a given jurisdiction directs the judge to apply the law of the place of contracting and the contract is deemed concluded by the lex fori in the state or country in which the acceptance is mailed and the law of the foreign state regards it as formed when the acceptance reaches the offeror, the law of the forum would necessarily have to control. However, if the law of the forum should have no other relation to the case than as the place of trial, and the laws of the foreign countries between which the negotiations were carried on should agree that a contract is completed at the

36. The Theory of Qualifications and the Conflict of Lazes (1920) 20 Cos. L. Rev. $247,250-252$.

37. For a discussion of the English and American cases, see Rodestsa: 22+229.

38. See Robertson 108; Lorenzen, supra note 36, at 24S-250; Restatese:t, Co:FLICT OF LAWS (1934) $\$ 10$.

39. See Restatearent, Conflict of Laws (1934) $\$ 10$, cavcaf. 
place where the acceptance reaches the offeror, uniformity in the Conflict of Laws would be promoted by accepting the foreign characterization.

Where the connecting factor has significance in the internal law of the country as well, it should conform for the purposes of the Conflict of Laws, to the international requirements, instead of being limited to the internal law concept. Our courts have shown an awareness of this fact in connection with domicile when they contrast "municipal" domicile with domicile for purposes of the Conflict of Laws. ${ }^{40}$

Robertson agrees that the connecting factor should generally be determined by the law of the forum. As he is inclined to accept the renvoi doctrine in the Conflict of Laws, he would, insofar as that doctrine applies, allow an exception to the above rule and accept the characterization of the connecting factor by the foreign law. ${ }^{41} \mathrm{He}$ gives as an illustration the case of an American citizen with a domicile of origin in Iowa who acquires a domicile of choice in England. He then decides to give up his English domicile and return to the United States to end his days. He dies on his way home. An English court is called upon to administer his estate. By English law the decedent died domiciled in Iowa because the domicile of origin automatically reverted upon the abandonment of his English domicile. By Iowa law, the decedent died domiciled in England because his English domicile of choice continued until a new domicile was established in Iowa. If, in the light of In re Annesley, ${ }^{42}$ the English judge is to decide the case in the same way as the judge sitting in the court of the domicile would do, he will have to follow the reference of Iowa law to English law in the matter of domicile. HIe would thus have to accept the determination of the connecting factor-domicile -by the Iowa court, instead of reaching a conclusion on the basis of the English law of domicile.

The case of University of Chicago v. Dater ${ }^{43}$ may be explained on this basis. A married woman in Michigan signed a note, dated and payable in Chicago, and secured by Illinois real estate. According to Michigan law, the contract was deemed concluded in Illinois. But when it was proved that under the Illinois rule as to the formation of contracts the contract was deemed concluded in Michigan, the Michigan court applied its own rule that the married woman was under a disability to enter into the contract. The majority opinion does not disclose any awareness of the problem involved. The dissenting opinion, on the other hand, clearly expresses the usual view toward this question. If, under the

40. "This is an illustration applicable to a change of municipal domicile. But the domicile required by the divorce statute seems to be more analogous to what is termed by Mr. Jacobs, in his work on Domicile, a quasi-national domicile." King v. King, 74 N. J. Eq. 824, 827, 71 Atl. 687,688 (1908).

41. ROBERTSON 110.

42. [1926] Ch. 692.

43. 277 Mich. 658, 270 N. W. 175 (1936). 
Michigan Conflicts rule, the law of the place where the contract was technically made determined the capacity of married women to contract, the Michigan court was obliged, of course, to ascertain where under the circumstances of the case the contract was made. This question the court resolved correctly on the basis of the Michigan decisions. The connecting factor was thereby established and there was no occasion to determine it over again on the basis of Illinois law. Therefore the court should have applied the Illinois law governing the capacity of married women to contract unless it was prepared to accept, with respect to contracts, the renvoi doctrine in the In re Annesley sense. Under the Annesley rule, the Michigan court should decide the case as the Illinois court would. It would be immaterial how the Illinois court reached its conclusion that Michigan law was applicable: whether it did so because its Conflict of Laws rule regarding capacity to contract was different from that of Michigan (it might determine such capacity with reference to the law of the domicile of the married woman), or whether the Conflicts rule regarding capacity to contract was the same as the Michigan rule but the Illinois court disagreed with the Michigan court's characterization of the connecting factor as the place of contracting.

A word of caution may be in order here. Although a goodly number of decisions and dicta in England seem to accept renvoi, there is no clear-cut decision by a higher court which really establishes the doctrine in English law. It should also be remembered that the English renvoi cases have been almost exclusively concerned with matters of succession where the English rule of domicile came into conflict with the continental rule of nationality. Moreover, even as limited to succession cases, the In re Annesley rule is only one of several interpretations which the English lower courts have given to the renvoi doctrine. Uniform results arose in In re Annesley from the fact that the French courts did not interpret their renvoi doctrine in the way the English court did. If the interpretation given to the renvoi doctrine by In re Anntesley is the true one on principle, it must be correct for every other country. If the French courts had interpreted their renvoi doctrine in the same way as In re Annesley, they would have had to decide the case in the same manner as an English court, and if an English court had to decide in the same way as a French court, no conclusion could have been reached. As long as some countries apply the renvoi doctrine in the French way, which is the traditional one, uniformity would be reached, with reference to those countries, on the basis of the In re Annesley doctrine. Personally, I cannot approve a doctrine which is workable only if the other country rejects it. Apart from that, I do not favor handing over our Conflicts problems to so-called experts on foreign private international law. It is difficult enough to get accurate expert testimony with respect to foreign municipal law, but such testimony is much more unreliable with respect to foreign Conflict of 
Laws. For these reasons I should still regard the general acceptance of the renvoi doctrine in our law as most unfortunate.

IV.

We come now to the third step in the solution of a Conflict of Laws problem, which is called by Robertson "The delimitation and application of the proper law." 44 In a case involving the distribution of personal property upon death, an Anglo-American court would find the connecting factor to be the decedent's domicile at the time of death and, characterizing this term on the basis of the lex fori, it might conclude that the domicile was in France. In a contract case, let us assume that a court has found it to be the settled law of the state that the law of the place of contracting controls, and, characterizing this connecting factor on the basis of the lex fori, let us assume that the court has found that the place of contracting was in France. In both instances the question will then be what is the French law that is to be applied? If the French law should have rules of the Conflict of Laws different from those of the forum, applying the national law of the decedent to questions of succession and the intention of the parties as governing the validity of the contract, we should be faced again with the renvoi doctrine, that is, whether the law of the forum should regard its Conflicts rules as referring to the French municipal or internal law (law of succession or contracts), exclusive of its rules of the Conflict of Laws, or the French law in its totality, including its rules of the Conflict of Laws. This assumes, of course, that the question is not regarded by the courts of the forum as one of procedure in the Conflicts sense. If it should be so regarded, the procedural rules of the forum would apply.

This is not the place to go further into the subject of renvoi in general. So far as it bears upon the question of characterization arising in connection with the third step in the solution of a Conflicts problem - the application and delimitation of the foreign law - it operates in the same manner as it operates in dealing with the qualification of the connecting factor. In other words, if the renvoi doctrine in the In re Annesley sense is adopted by the law of the forum, the court would have to regard itself in the above cases as sitting in France and decide the case as a French court would decide it. ${ }^{45}$ If a question of qualification were involved, it would mean, of course, that the law of the forum would follow the decision of the French court. To the extent, therefore, that the law of the forum accepts the renvoi in the In re Amnesley sense, any qualification

44. ROBERTSON 17-18.

45. Falconbridge is of the opinion that the renvoi doctrine should be recognized with respect to status, and for that reason he would justify characterization of status on the basis of the foreign law governing such status. Characterization in the Conflict of Lawes (1937) 53 L. Q. REv. 235, 544-546; Conflict of Laws: Examples of Characterization (1937) 15 CAN. B. Rev. 215, 244. 
arising in the application or delimitation of the French law would actually be determined by the lex causae.

As the renvoi doctrine has not been recognized in American law, except for certain purposes, let us consider the claracterization problem arising in connection with the third step in the solution of a Conflict of Laws problem (the application and delimitation of the foreign law) on the assumption that the Conflicts rules of the forum apply strictly to the internal law of the foreign country and not to its Conflicts rules. Robertson calls this the problem of secondary classification and argues that secondary classification should be on the basis of the lex causue on principle, and not merely by way of exception, as in the case of primary characterization. He thus accepts Bartin's later generalization, ${ }^{30}$ according to which the law of the forum disinterests itself in the case after it has chosen the foreign law and turned the case over to such law, so that any problem of characterization arising in the application of the foreign law will be governed by that law. Cheshire drew the same distinction between questions of characterization arising before and after the foreign law has been chosen by the lex fori. We find, however, that these supporters of the secondary classification theory do not agree among themselves as to the types of cases which are subject to secondary characterization. Robertson goes beyond Cheshire, by including in this class the question whether a legal provision relates to capacity or formalities.

The two cases generally discussed in this connection by writers on the qualification problem are a Dutch will case and the English case of Ogden $v$. Ogden. ${ }^{47}$ The former involved a holographic will made by a Hollander in France, ${ }^{48}$ the Dutch law prohibiting Hollanders from executing their wills in the holographic form either at home or abroad. ${ }^{.9}$ Bartin originally regarded this situation as one in which no uniformity of decision could be reached, on the assumed ground that from the Dutch point of view the question would be one of capacity while from the standpoint of French law it would be one of formality. ${ }^{50}$ The Dutch courts would regard the will as void, whereas the courts of the country in which the will was executed or the courts of third countries might apply the law of the place of execution to matters of formality and so hold the will valid. This viewpoint has had the approval both of courts ${ }^{51}$ and

46. Bartin, La Doctrine des Qualifications et ses rapports atec le caracticre vationas des règles du Conflit des Lois (1930) Acídearre dE DR. INT., Rec. des Cours I, 565, 608.

47. [1908] P. 46.

48. A similar question is presented by the prohibition of joint wills, which is regarded by some as appertaining to capacity and by others as appertaining to form.

49. Holland: Civil CoDE (1921) art. 992.

50. 24 Clunet 225, 229-230.

51. France: Cass. (Civ.) Aug. 25, 1847, Dalloz Jurisprudence, 1847 I. 273; Gicrmany: Hans. OLG, Mlay 2, 1917, Hans. G.Z., 1917, Beibl., 252. 
writers. $^{52}$ Cheshire regards the problem as one of primary characterization, to be determined on the basis of the lex fori. ${ }^{53}$ According to Robertson's theory of secondary characterization, if such a will, disposing of movable property, is executed in England, and the English courts regard the law of domicile as governing capacity to make a will and the law of the place of execution as governing formalities, the courts should inquire of the Dutch law what it understands by capacity and of the English law what it means by formalities. ${ }^{54}$ Others have denied the validity of the will anywhere, either because they regarded the Dutch legislation as affecting capacity and therefore governed by the testator's personal (Dutch) law ${ }^{55}$ or, conceding that the Dutch statute affected formalities, because they did not attribute an absolute character to the rule that the law of the place of execution governed formalities, but regarded it, with respect to Dutch nationals, as stubject to modification by the national legislation. ${ }^{58}$ Bartin seems to have adopted this view in his later years. ${ }^{57}$ From the standpoint of the Dutch law, the will would be invalid without any need of characterizing the legislation as relating to capacity or to form. ${ }^{58}$ The case presented, therefore, is in reality not at all a problem of differences in qualification.

The facts in Ogden v. Ogden were as follows: In 1898 a marriage was celebrated in England between Sarah, a domiciled Englishwoman, and Philip, a domiciled Frenchman, who was 19 years of age. In 1901 this marriage was annulled by a French court on the ground that the consent of Philip's surviving parent had not been obtained as required by French law. Philip subsequently married a French woman in France. Sarah thereupon, in 1903, instituted a suit in England for the dissolution of her marriage with Philip on the ground of his adultery and desertion. This suit was dismissed for want of jurisdiction because Philip was domiciled

52. 1 Arminjon, Précis de Dr. Int. Privé (2d ed. 1927) 135; 6 Straudingero's Kommentar zum Bürgerlichen Gesetzbuche (Raape's 9th ed. 1931), part II, 18. Sec also Pillet \& Niboyet, Manuer de Dr. Int. Privé (1928) 503; Disspagnet, Précis de: Dr. Int. Privé (5th ed. 1909) 354; Surville, Cours Élémentalre de Dr. INr. Privé (7th ed. 1925) 19, n. 3.

53. Private International Law (2d ed. 1938), 34 ct seq.

54. ROBERTSON 238, 244-245.

55. In favor of this view: France: Dufour v. Dufour, Trib. Seinc, Aug. 13, 1903, 31 Clunet 166; Belgitm: Willemsen v. Brands, Trib. Brussels, July 21, 1886, 14 Clunet 495; Isabaert v. Barbiaux, Trib. Termonde, March 24, 1907, 35 Clunet 885; Froidbise v. Horsten, App. Brussels, Jan. 9, 1937, Pas. 1937, II. 56.

56. France: Leeuwn v. Guilbot, Trib. Seine, Feb. 19, 1927, 55 Clunet 707; Italy: Ogtrop v. Formica, App. Genoa, Aug. 4, 1891, 20 Clunet 955, aff'd, Cass. Turin, Apr. $12,1892,21$ Clunet 1083. This would be tantamount to the recognition of a new choiceof-law rule with respect to formalities.

57. Bartin, supra note 46 , at 576 .

58. Kosters, Het Internationant Burgerlijk Recht in Nederland (1917) 643; Amsterdam, Rechtbank, June 19, 1924, 12 Bull. de L'institut Intermédiare International 118. 
in France. In 1904 Sarah, describing herself as a widow, married Ogden, a domiciled Englishman, in England. In 1906 Ogden obtained an annulment of the marriage on the ground that at the time of their marriage Sarah was married to Philip. So far as Ogden i'. Ogden held that the French decree of nullity was not entitled to recognition in England, it is deemed overruled by subsequent English cases. The case is principally of interest because of the problem of qualification involved in it and the decision that the requirement of parental consent to the marriage was to be characterized as a part of the formalities, so that the marriage between Sarah and Philip was validly contracted from the English point of view.

Various solutions of the Ogden problem have been suggested. Beckett would give effect to all French provisions, though relating to formalities abroad, for the reason that they are matters of family law and intended for the protection of family interests. ${ }^{60}$ Cheshire $^{60}$ and Falconbridge ${ }^{01}$ insist that the qualification of the French requirement must be according to the lex fori. Says Cheshire:

"In order to reach a decision, he [the English judge] examines the terms in which the rule is expressed, and he considers the construction put upon it by French expert witnesses, but he must ultimately determine its true nature by an application of the canons and principles recognized in England. If the rule reads as follows:

'The son who has not reached the age of 25 years cannot contract marriage, without the consent of his father and mother,'

it would seem that it must be classed as affecting the capacity of the parties. . . . If an English judge applies French law merely because a French lawyer would regard the question sub judice as one of capacity, though in England it is regarded as one of formal validity, the result is the application of a legal system which in this country is considered inappropriate in the matter at hand." 02

If the English rule that capacity to contract a marriage is governed by the law of domicile is a general one, its characterization should be on the basis of the lex fori and not on that of the lex causae. The ultimate question is whether French or English law is to be applied to the matter of consent of parents. The answer to the question depends upon

59. Beckett, The Question of Classification ("Qualification") In Prizale Inlernafional Law (1934) 15 BrIt. Y. B. Ixт. L. 46, 78.

60. Private International Law (2d ed. 1938) 36.

61. Characterization in the Conffict of Laws (1937) 53 L. Q. REv. 235, 249 (maintains that parental consent cannot be characterized in the abstract; that it may be a question of formality in one context and capacity in another).

62. Primate International Law (2d ed. 1938) 36, 37. In applying the forcign law selected by the forum, the court should take into consideration all relevant provisions, though they may appear in some other title or division of the Code. 
whether the consent of parents is to be characterized as appertaining to capacity or form. This question the law of the forum must decide for itself. If the English judge were to submit to the French view in this situation and regard a French provision as one of capacity when from the English point of view it is a matter of form, he would, as Cheshire points out in the above quotation, apply a law which is considered inappropriate by the law of the forum. He would apply French law because of the French characterization when he should apply English law according to the English characterization. As well might the English judge prefer the French to the English rules for the choice of law, i.e., accept the renvoi doctrine. Robertson appears to favor the renvoi and this no doubt accounts for his suggestion that in the case of multiple qualification (where, for example, capacity is governed by the law of clomicile and formalities by the law of the place where the transaction occurs), the characterization should be on the basis of the lex causae (i.e., the clomiciliary law should characterize capacity and the lex loci actus should characterize matters of form). That suggestion is unacceptable.

Both Cheshire and Robertson assume that there is an established rule in the English Conflict of Laws that capacity to marry is governed by the law of domicile and formalities by the law of the place of celebration. If the English rule that the law of domicile controls the capacity to marry were of a more restricted character so as to be limited (as submitted by Neuner and Rheinstein ${ }^{63}$ ) to degrees of relationship, all other matters being subject to the law of the place of celebration, the marriage in Ogden v. Ogden would of course have been valid in England, but no question of characterization would have been presented.

The problem remains whether or not questions of qualification which may arise after the foreign law has been chosen by the lex fori should be referred to the foreign law (lex causae) as Bartin, Cheshire and Robertson advocate. It goes without saying that if the qualification problem merely involves the application of the foreign internal law, the foreign law should control. The law of state $X$, which has been chosen by the law of the forum as governing a contract or tort, necessarily governs any subsidiary question relating to such contract or tort; for example, whether a particular contract is to be regarded as a loan or deposit, or whether the master is responsible for the torts of his servants, and what is meant by master and servant in that connection. It is also reasonable that if the French Civil Code permits Frenchmen to execute wills in the "authentic" form abroad, the requirement may be deemed satisfied if the nearest equivalent existing in the place of execution is complied with (for example, where a will is executed in England before witnesses).

63. See Neuner, op. cit. supra note 15. Compare also Rheinstein, Book Review (1938) 8 BROOKLYN L. Rev. 253, 257. 
Does it follow that the lex causae should likewise determine whether a particular provision of the foreign law relates to substance or procedure? The principal examples of secondary qualification given by Cheshire relate to substance and procedure. Robertson also dwells at length upon this subject in his discussion of secondary characterization. According to these writers, if the law of the forum has decided that a contract or a tort is governed by the law of state $X$ and no rules of procedure of the forum are involved, such questions as whether a writing required by the law of state $X$ affects the formation and validity of the contract or relates to evidence, whether by the law of state $X$ the running of the statute of limitations discharges a contract or merely bars the remedy for its breach, whether the failure to give notice to the wrong-doer required by the law of state $X$ will discharge the cause of action or whether it is merely a procedural requirement for the bringing of the suit, should be governed by the law of state $X$. What are the consequences of this view? According to the proponents of the secondary classification theory. if the law of the forum says that the statute of limitations is substantive and the law governing the contract says it is procedural, the action would be maintainable, even though it is not brought within the time prescribed by either law. ${ }^{64}$ The statute of limitations of the forum would be applicable only to contracts governed by the law of the forum and the foreign statute of limitations, being procedural, would be disregarded, as the courts do not enforce the procedural laws of another country. The same would be true in the case of the statute of frauds. If the law of the forum says it is substantive and the law governing the contract says it is procedural, the contract would be enforceable upon reasoning similar to that used in connection with the statute of limitations, although neither statute is satisfied. ${ }^{e 5}$ If the law of the forum should have a substantive

64. This is the view taken by Cheshire and Robertson. To the same effect with respect to the Statute of Frauds, see Wrarton, Conflict of Laws (3d ed. 1905) 1445. If it should be asked why, under the secondary classification theory, the characterization by the foreign law of the Statute of Limitations or of the Statute of Frauds as procedural was not binding upon the courts of the forum so as to make the statute of the forum applicable, the answer is, because the law of the forum, in submitting the matter to the foreign law, has thereby already decided that the question is one of substance. Procedural matters are always subject to the law of the forum.

65. The German Supreme Court took this view in a suit upon a Tennessee contract. The German statute ( 3 years) did not apply because it was regarded as substantive and thus applicable only to contracts governed by German law. The Tennessce statute 6 years) was found to be procedural from the viewpoint of American law and hence not applicable. There being no statute of limitations applicable to the situation, the action was allowed. German Supreme Court, January 4, 18S2, 7 RGZ 21. Later cases have taken the view advocated in this Article: that the foreign statute be qualified on the basis of the law of the forum. After a detailed comparison between the eficets of the forcign statute and the German statute of limitations the court found that they vere substantially the same. That being the case, it felt that the case could be dealt with on the basis of German law, which had rejected the notion, formerly prevailing, that the statute of 
rule requiring notice of the injury suffered by the plaintiff and the law of the place where the injury arose should regard the requirement of notice as a matter of procedure, the action would lie, although no notice was given, that is, neither law was complied with. If the law of the forum should regard the burden of proof as substantive and the law of the state where the wrong was committed should regard it as procedtural, there would theoretically be no law applicable to the burden of proof. ${ }^{60}$

Results like these would seem sufficient to prove the unsoundness of the secondary classification theory. If an applicable foreign statute of frauds or statute of limitations has not been satisfied, the plaintiff has no right to damages for the breach of the contract under the law governing the contract. If this is so, there is no reason why the plaintiff should be given greater rights in any other state. The very object of the rules of the Conflict of Laws is to keep the rights of parties the same, regardless of the state or country in which the litigation may take place. If the law of the forum chooses the law of state $X$ as governing the contractual rights of the parties, it does so on considerations of fairness and justice. If the law of the foreign state or country says that the plaintiff never had an enforceable right, he should not have an enforceable right anywhere else. An unenforceable right is equivalent for purposes of the Conflict of Laws to no right. The statement that courts should enforce foreign substantive rights but not foreign procedural laws has no justifiable basis if the so-called procedural law would normally affect the outcome of the litigation. If there is any sense in the proposition that the law of state $X$ governs the contract - and if there is no sense in that proposition, the entire Conflict of Laws should be scrapped - it must mean that all municipal laws of the state normally affecting the rights of the parties (that is, the recovery of damages), such as the statute of frauds and the statute of limitations, should control.

The parties cannot, of course, expect the courts of the forum to adapt their legal machinery to that of any foreign state or country. So far as the detailed steps and modes of procedure are concerned, courts can operate only in their accustomed manner. A Connecticut court cannot without undue inconvenience try a case in accordance with New York procedure and it would be quite impossible to try a case in accordance with a continental or Latin-American system of procedure. The law of the forum is thus obliged, on grounds of necessity, to apply its own pro-

limitations belongs to the law of procedure. RG, Nov. 21, 1910, Iuristische Wochenschrift 1911, 148; July 6, 1934, 145 RGZ 121.

Nussbaum regards the analysis and appraisal of the integration process-the process of deternining whether the foreign institution conforms substantially to that of the for um -as constituting the central problem of qualification, which is rarely touched upon by the writers on the subject. Book Review (1940) 40 Col. L. Rev. 1461, 1465; cf. Wood \& Selick v. Compagnie Générale Transatlantique, 43 F. (2d) 941 (C. C. A. 2d, 1930).

66. In this predicament the court would probably apply the law of the forum. 
cedural laws and disregard those of other states. However, foreign statutes of limitations and statutes of frauds do not fall within that category, for they can be proved as readily and without greater inconvenience than any other foreign law that may be applicable under the rules of the Conflict of Laws of the forum.

\section{V.}

We have arrived, then, at the following conclusions:

(1) The question whether a situation is to be classified as one of contracts, torts, succession, matrimonial property, and the like, is necessarily to be determined by the law of the forum. The foreign institution need not conform strictly to the internal law of the forum; it should be sufficient if it falls within its analytical framework or within some special concept worked out for purposes of the Conflict of Laws.

(2) The same conclusion applies to the characterization of the connecting factor. However, to the extent that the law of the forum accepts the renvoi doctrine in the In re Annesley sense, the characterization of the connecting factor by the foreign law would prevail.

(3) As the law of the forum is chosen in the above classes of cases for want of any other practicable rule, it should be abandoned whenever some other reasonable solution can be found. For that reason the question whether tangible property is movable or immovable should be determined on the basis of the law of the situs. Again, if the fact situation is exclusively connected with foreign states or countries, the law of the forum being interested solely as the place of trial, a common characterization placed upon it by the law of all the foreign states or countries involved should be accepted.

To the extent that the law of the forum understands its Conflicts rules in the renvoi (In re Annesley) sense, the adoption of the characterization made by the foreign law would follow.

(4) The suggestion that the lex cansae should determine all questions of characterization arising after the foreign law has been selected by the lex fori - the "secondary characterization" of Cheshire and Robertson is not to be approved. As in the preceding cases, such questions of characterization should be resolved on the basis of the lex fori. 